\title{
Assessment of Gastroenteric Viruses from Wastewater Directly Discharged into Uruguay River, Uruguay
}

\author{
M. Victoria $\cdot$ L. F. L. Tort $\cdot$ M. García $\cdot$ \\ A. Lizasoain - L. Maya $\cdot$ J. P. G. Leite \\ M. P. Miagostovich $\cdot$ J. Cristina $\cdot$ R. Colina
}

Received: 31 October 2013/Accepted: 24 March 2014/Published online: 29 April 2014

(C) Springer Science+Business Media New York 2014

\begin{abstract}
The aim of this study was to assess the viral contamination of group A rotavirus (RVA), norovirus (NoV), and human astrovirus (HAstV) in sewage directly discharged into Uruguay River and to characterize RVA genotypes circulating in Uruguay. For this purpose, sewage samples $(n=96)$ were collected biweekly from March 2011 to February 2012 in four Uruguayan cities: Bella Unión, Salto, Paysandú, and Fray Bentos. Each sample was concentrated by ultracentrifugation method. Qualitative and quantitative RT-PCR for RVA, NoV, and HAstV were performed. A wide dissemination of gastroenteric viruses was observed in the sewage samples analyzed with $80 \%$ of positivity, being NoV $(51 \%)$ the most frequently detected followed by RVA with a frequency of $49 \%$ and HAstV with $45 \%$. Genotypes of RVA were typed using multiplex semi-nested RT-PCR as follows: P[8] $(n=15), \mathrm{P}[4]$ $(n=8), \mathrm{P}[10](n=1), \mathrm{P}[11](n=1), \mathrm{G} 2(n=29)$, and $\mathrm{G} 3(n=2)$. The viral load ranged from $10^{3}$ to $10^{7}$ genomic copies/liter, and they were detected roughly with the same frequency in all participant cities. A peak of RVA and
\end{abstract}

M. Victoria - L. F. L. Tort · M. García · A. Lizasoain · L. Maya $\cdot$ R. Colina $(\bowtie)$

Laboratorio de Virología Molecular - Regional Norte,

Universidad de la República, Gral. Rivera 1350, 50000 Salto,

Uruguay

e-mail: rodneycolina1@gmail.com

J. P. G. Leite - M. P. Miagostovich

Laboratorio de Virologia Comparada y Ambiental, Instituto

Oswaldo Cruz, FIOCRUZ, Av. Brazil 4365, Manguinhos,

Rio de Janeiro 21040-360, Brazil

J. Cristina

Laboratorio de Virología Molecular, Centro de Investigaciones Nucleares, Facultad de Ciencias, Universidad de la República, Iguá 4225, 11400 Montevideo, Uruguay
HAstV detection was observed in colder months (June to September), whereas no seasonality was observed for NoV. This study demonstrates for the first time, the high degree of gastroenteric viral contamination in the country; highlighting the importance of developing these analyses as a tool to determine the viral contamination in this hydrographic boundary region used by the local populations for recreation and consumption, establishing an elevated risk of gastroenteric diseases for human health.

Keywords Sewage samples · Group A rotavirus . Norovirus · Human astrovirus · RT-PCR

\section{Introduction}

Diarrhea remains the second leading cause of death among children under 5-years old globally, causing about 1.3 million preventable deaths each year, mainly in developing countries (WHO 2009a; Wazny et al. 2013). Considering this alarming data, $88 \%$ of them are attributable to unsafe water, inadequate sanitation, and poor hygiene. Improvements in access to safe water and adequate sanitation can help in preventing this elevated number of deaths caused by diarrhea (Black et al. 2003).

Group A rotavirus (RVA) and norovirus (NoV) are the most important gastroenteric viruses that cause diarrhea and others symptoms of acute gastroenteritis like vomit and abdominal pain (Churgay and Aftab 2012; Payne et al. 2013). They are excreted in feces from infected persons during the period of acute diarrhea at high concentrations that can reach up to $10^{11}$ viral particles per gram of feces in the case of RVA and NoV (Desselberger 1999; Chan et al. 2006). Gastroenteric viruses can be excreted after the period of acute diarrhea and also in asymptomatic patients 
(Gallimore et al. 2004; O'Ryan et al. 2009; Barreira et al. 2010).

The dissemination of these pathogens in the environment is due to the discharge of wastewater (treated or not) collected from the cities into surface waters like rivers or lagoons. These viruses are resistant to adverse conditions of the environment and persist for long periods in environmental waters without losing its infectivity capacity, originating a risk of infecting people that enter in contact with these waters mainly due to their low infectious dose (approximately 10 viral particles for NoV) (Teunis et al. 2008; Seitz et al. 2011). It́s has been demonstrated that rotavirus and human astrovirus (HAstV) can persist infective for several days in surface water and months in groundwater (Espinosa et al. 2008). Enteroviruses can be detected and isolated in different non-treated and treated sources of water like sewage, river, borehole, spring, and dam water as well as in drinking water (Ehlers et al. 2005). Furthermore, after chlorine or UV treatments, gastroenteric viruses can replicate as well, and as a consequence, the inactivation procedure has to be adjusted depending on type of virus (Gerba et al. 2002; Li et al. 2009).

The identification of gastroenteric viruses in different environmental samples like sewage, surface, and marine water is well documented, especially in developed countries and are useful, because they reflect their circulating in a given geographic region; however, this information is scarce in developing countries like Uruguay (Pina et al. 1998; Calgua et al. 2008; Wyn-Jones et al. 2011). In this study, the distribution of RVA, NoV, and HAstV was determined, to our knowledge, for the first time in Uruguay by analyzing wastewater directly discharged to Uruguay River in four cities located in the Northwestern region of Uruguay.

Uruguay River conforms a large hydrographic boundary region, thus, constitutes an important geographical model to study the impact of human activity and environmental viral contamination of surface waters. The river covers a distance of approximately $1,838 \mathrm{~km}$ long, of which $1,262 \mathrm{~km}$ is located in Brazil and corresponds to the stretch between its headwaters and the confluence with Quaraí River. The remaining $576 \mathrm{~km}$ is located between Uruguay and Argentina and constitutes the border among both countries. Uruguay River waters pass through three different countries, each of them with their own climatic, demographic, ecological, and epidemiological characteristics. Five dams were built on the river to generate electricity, and 975,000 inhabitants are living on its shores. Historically, these populations have lived along the river and have exploited its wealth in various aspects like fisheries, navigation, energy production, as well as using its water for domestic consumption, irrigation, and recreation (C.A.R.U. 2013).

\section{Materials and Methods}

Area and Strategy of the Study

Uruguay River is located in South America and flows from North to South bordering Brazil, Argentina, and Uruguay, starting in Serra do Mar, Brazil. It flows between the states of Santa Catarina and Rio Grande do Sul in Brazil, from the Eastern border of the provinces of Misiones, Corrientes, and Entre Ríos in Argentina and makes up the Western borders of Artigas, Salto, Paysandú, Río Negro, Soriano, and Colonia departments in Uruguay (I.B.G.E. 2013; I.N.D.E.C. 2013; I.N.E. 2013).

The area of this study was demarked in the Northwest region of Uruguay including four cities: Bella Unión $\left(30^{\circ} 15^{\prime} 59.55^{\prime \prime} \mathrm{S}, \quad 57^{\circ} 36^{\prime} 4.79^{\prime \prime} \mathrm{W}\right), \quad$ Salto $\quad\left(31^{\circ} 23^{\prime} 18.82^{\prime \prime} \mathrm{S}\right.$, $\left.57^{\circ} 58^{\prime} 35.09^{\prime \prime} \mathrm{W}\right)$, Paysandú (32॰19'38.38' $\left.\mathrm{S}, 58^{\circ} 6^{\prime} 3.83^{\prime \prime} \mathrm{W}\right)$, and Fray Bentos $\left(33^{\circ} 7^{\prime} 8.95^{\prime \prime} \mathrm{S}, 58^{\circ} 20^{\prime} 3.38^{\prime \prime} \mathrm{W}\right)$ (Fig. 1). All these cities are located along Uruguay River covering three quarters of its extension in the Uruguayan territory with approximately $330 \mathrm{~km}$ between Bella Unión and Fray Bentos. One sampling collection site was determined in each city. Sewage samples from Salto, Paysandú, and Fray Bentos were collected in a collector which directly discharges untreated sewage into the river. Regarding Bella Union, sewage samples (effluent) were collected downstream of the stabilization pond.

\section{Collection and Concentration of Wastewater Samples}

$42 \mathrm{ml}$ of sewage sample $(n=96)$ was collected biweekly in each city from March, 2011 to February, 2012. The samples were collected and rapidly refrigerated at $4{ }^{\circ} \mathrm{C}$. They were immediately transported to the Molecular Virology Laboratory at Salto city in a maximum time of $3 \mathrm{~h}$. The samples were kept at $4{ }^{\circ} \mathrm{C}$ and processed for viral concentration in the following $12 \mathrm{~h}$ and stored at $-80^{\circ} \mathrm{C}$, until utilized for virus detection assays.

Viral concentration was carried out using ultracentrifugation methodology as described by Pina et al. (1998) with modifications added by Fumian et al. (2010). Briefly, $42 \mathrm{ml}$ of sewage was ultracentrifuged at $100,000 \times g$ for $1 \mathrm{~h}$ at $4{ }^{\circ} \mathrm{C}$. Viral particles were resuspended in $3.5 \mathrm{ml}$ of $0.25 \mathrm{~N}$ glycine buffer (pH 9.5) and incubated on ice for $30 \mathrm{~min} .3 .5 \mathrm{ml}$ of $2 \mathrm{X}$ phosphate-buffered saline (PBS, $\mathrm{pH} 7.2$ ) was added to neutralize the solution and was centrifuged at $12,000 \times g$ for $15 \mathrm{~min}$. The supernatant was ultracentrifuged again at $100,000 \times g$ for $1 \mathrm{~h}$ at $4{ }^{\circ} \mathrm{C}$, and $200 \mu \mathrm{l}$ of $1 \mathrm{X}$ PBS was added to resuspend the pellet. All analyzed samples were spiked with $500 \mu$ of a culture suspension containing PP7 bacteriophage, used as an internal control, kindly provided by Dr. Veronica Rajal from the National University of Salta, Argentina. The concentration of PP7 used was $1 \times 10^{8}$ genomic copies/ml. The quantification of PP7 was performed 


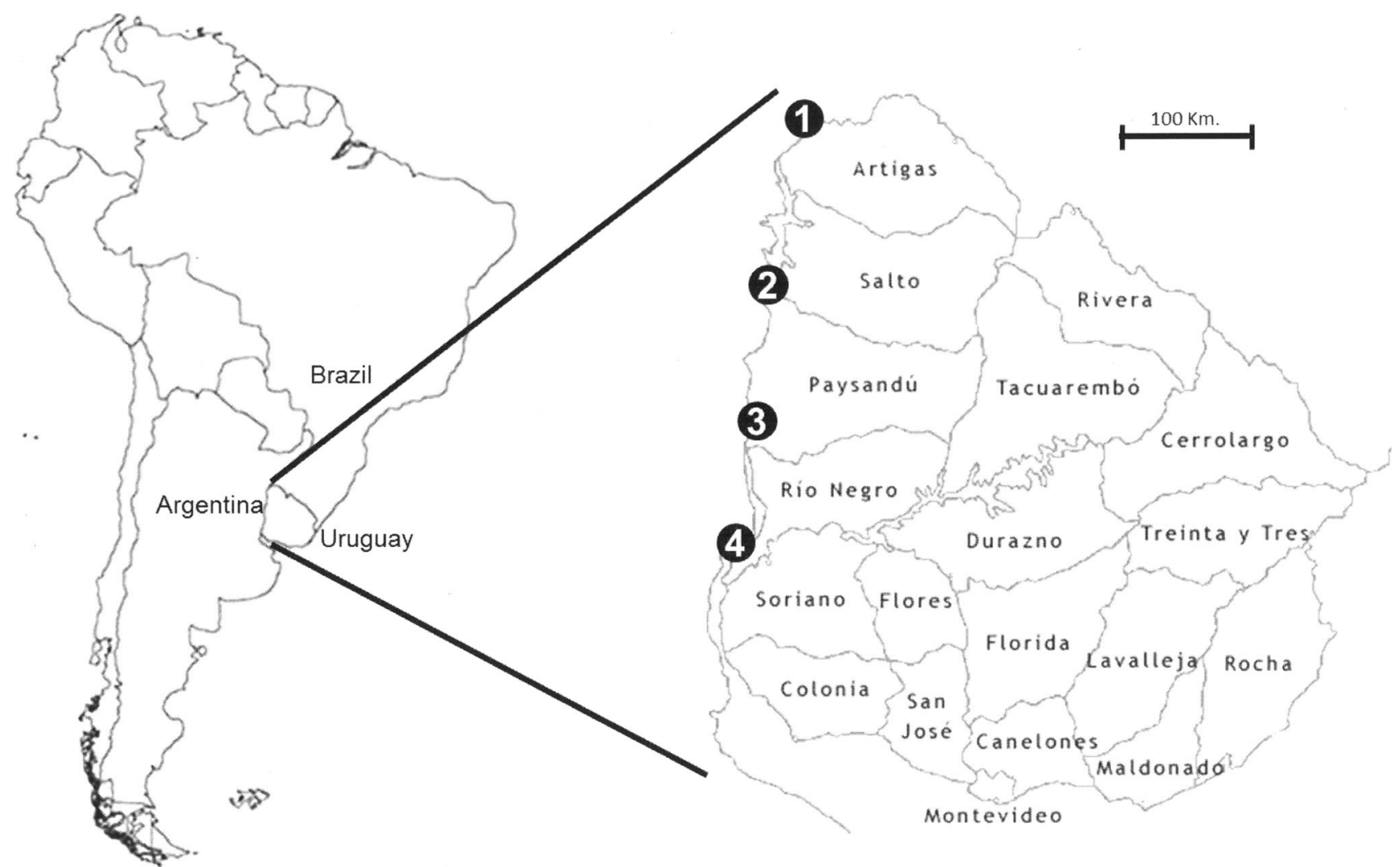

Fig. 1 Map of collection sites (black circles with numbers) located in four cities along Uruguay River: Bella Unión (1), Salto (2), Paysandú (3), and Fray Bentos (4)

by real time PCR in the Laboratory of Comparative and Environmental Virology, FIOCRUZ, Rio de Janeiro, Brazil.

Nucleic Acids Extraction and cDNA Synthesis

$200 \mu \mathrm{l}$ of $1 \mathrm{X}$ PBS was added to the $200 \mu \mathrm{l}$ of the concentrated sample to obtain a final volume of $400 \mu \mathrm{l}$ in order to perform the nucleic acids extraction that was carried out using guanidium/silica method (Boom et al. 1990). Reverse transcription (RT) of the viral RNA was carried out with random hexamers (SBS Genetech ${ }^{\mathrm{TM}}$ ) and SuperScript ${ }^{\mathrm{TM}} I I$ Reverse Transcriptase (Invitrogen ${ }^{\mathrm{TM}}$ ) according to the manufactureŕs instructions. In all the procedures, pure RNAse-and DNAse-free water was used as negative controls, and $10 \%$ fecal suspension of RVA, NoV, and AstV previously characterized as G1P[8] (Accession number: K02033 and L34161), GII.4 (Accession number: JX975552), and HAstV-1 (Accession number: JQ796912), respectively, was used as positive controls.

Qualitative PCR for PP7 bacteriophage, Group

A Rotaviruses, Noroviruses, and Human Astroviruses

For detection of the internal control (PP7), a qualitative PCR was performed in a final volume of $25 \mu \mathrm{l}$ containing final concentration of $0.4 \mu \mathrm{M}$ of primers $247 \mathrm{f}$ and $320 \mathrm{r}$, $20 \mathrm{mM}$ Tris- $\mathrm{HCl}$ (pH 8.4), $50 \mathrm{mM} \mathrm{KCl}, 1.6 \mathrm{mM} \mathrm{MgCl}$, $0.2 \mathrm{mM}$ of each dNTP, 1U of Taq DNA Polymerase (Invitrogen ${ }^{\circledR}$ ), and $5 \mu \mathrm{l}$ of cDNA. The amplification was performed with 40 cycles $\left(94{ }^{\circ} \mathrm{C}, 30 \mathrm{~s} ; 60^{\circ} \mathrm{C}, 1 \mathrm{~min}\right.$; and $72{ }^{\circ} \mathrm{C}, 30 \mathrm{~s}$ ) followed by a final extension at $72{ }^{\circ} \mathrm{C}$ for 10 min (Rajal et al. 2007).

Detection and genotyping of RVA were achieved by using qualitative multiplex semi-nested RT-PCR for VP4 and VP7 genes. The first round PCR for VP4 (primers $4 \operatorname{con} 3$ and 4con2) and VP7 (primers 9con1 and 9con2) genes was performed with the same reagents and concentration as described for PP7 PCR with the exception of $2.5 \mu \mathrm{l}$ of cDNA (WHO 2009b). The first round of VP4 and VP7 PCR was carried out with 35 cycles of $94{ }^{\circ} \mathrm{C}, 30 \mathrm{~s}$; $50{ }^{\circ} \mathrm{C}, 30 \mathrm{~s}$; and $72{ }^{\circ} \mathrm{C}, 1 \mathrm{~min}$ followed by a final extension at $72{ }^{\circ} \mathrm{C}$ for $10 \mathrm{~min}$. The second round multiplex-PCR for VP4 (4con3, 1T-1, 1T-1Wa, 1T1-VN, 2T-1, 3T-1, 4T-1, 5T-1, ND2, p4943) and VP7 (9con1, 9T-1, 9T-2, 9T-3, 9T4, 9T-9) was performed with the same reagent, concentration and cycling conditions as mentioned for the first round VP4 and VP7 PCR with the exception of $1 \mu \mathrm{l}$ of template.

NoV GI and GII detections were carried out using a semi-nested RT-PCR. The first round PCR with primers 
Table 1 Primers used for detection and typing of viruses by qualitative PCR

\begin{tabular}{|c|c|c|c|c|c|}
\hline Virus & Primer & Sequence $\left(5^{\prime} \rightarrow 3^{\prime}\right)^{\mathrm{a}}$ & Genome region & Amplicon size & Reference \\
\hline \multirow[t]{18}{*}{ RV } & $9 \operatorname{con} 1$ & TAGCTCCTTTTAATGTATGG & VP7 & 904 bp & WHO 2009b \\
\hline & $9 \operatorname{con} 2$ & GTATAAAATACTTGCCACCA & & & \\
\hline & $9 \mathrm{~T}-1$ & TCTTGTCAAAGCAAATAATG & VP7 & $158 \mathrm{bp}$ & \\
\hline & $9 \mathrm{~T}-2$ & GTTAGAAATGATTCTCCACT & VP7 & 244 bp & \\
\hline & $9 \mathrm{~T}-3$ & GTCCAGTTGCAGTGTAGC & VP7 & 484 bp & \\
\hline & $9 \mathrm{~T}-4$ & GGGTCGATGGAAAATTCT & VP7 & $403 \mathrm{bp}$ & \\
\hline & $9 \mathrm{~T}-9$ & TATAAAGTCCATTGCAC & VP7 & $110 \mathrm{bp}$ & \\
\hline & $4 \operatorname{con} 3$ & TGGCTTCGCTCATTTATAGACA & VP4 & $876 \mathrm{bp}$ & WHO 2009b \\
\hline & $4 \operatorname{con} 2$ & ATTTCGGACCATTTATAACC & & & \\
\hline & $1 \mathrm{~T}-1$ & TCTACTTGGATAACGTGC & VP4 & $345 \mathrm{bp}$ & \\
\hline & $1 \mathrm{~T}-1 \mathrm{Wa}$ & TCTACTGGGTTAACGTGC & VP4 & $345 \mathrm{bp}$ & \\
\hline & $1 \mathrm{~T} 1-\mathrm{VN}$ & TCTACTGGATCGACGTGC & VP4 & $345 \mathrm{bp}$ & \\
\hline & $2 \mathrm{~T}-1$ & CTATTGTTAGAGGTTAGAGTC & VP4 & $483 \mathrm{bp}$ & \\
\hline & $3 \mathrm{~T}-1$ & TGTTGATTAGTTGGATTCAA & VP4 & $267 \mathrm{bp}$ & \\
\hline & $4 \mathrm{~T}-1$ & TGAGACATGCAATTGGAC & VP4 & $391 \mathrm{bp}$ & \\
\hline & $5 \mathrm{~T}-1$ & ATCATAGTTAGTAGTCGG & VP4 & $583 \mathrm{bp}$ & \\
\hline & ND2 & AGCGAACTCACCAATCTG & VP4 & $122 \mathrm{bp}$ & \\
\hline & $\mathrm{p} 4943$ & GGTGTAGTTCCTGCGTA & VP4 & $543 \mathrm{bp}$ & \\
\hline \multirow[t]{4}{*}{ NoV } & JV12Y & ATACCACTATGATGCAGAYTA & RNA polymerase & 327 bp & Boxman et al. 2006 \\
\hline & JV13I & TCATCATCACCATAGAAIGAG & & & \\
\hline & G1 & TCNGAAATGGATGTTGG & & $187 \mathrm{bp}$ & \\
\hline & Noroll-R & AGCCAGTGGGCGATGGAATTC & & $236 \mathrm{bp}$ & \\
\hline \multirow[t]{2}{*}{ HAstV } & Mon269 & CAACTCAGGAAACAGGGTGT & ORF2 & 449 bp & Noel et al. 1995 \\
\hline & Mon270 & TCAGATGCATTGTCATTGGT & & & \\
\hline \multirow[t]{2}{*}{ PP7 } & $247 \mathrm{f}$ & GTTATGAACCAATGTGGCCGTTAT & Replicase & $73 \mathrm{bp}$ & Rajal et al. 2007 \\
\hline & $320 \mathrm{r}$ & CGGGATGCCTCTGAAAAAAG & & & \\
\hline
\end{tabular}

$R V$ rotavirus, $N o V$ norovirus, $H A s t V$ human astrovirus, $P P 7$ PP7 bacteriophage

${ }^{a}$ Degenerated primers and probes are as follows: Y: C or T; R: A or G; B: not A; N: any. W: A or T; K: G or T; S: G or C

JV12Y and JV13I detects both GI and GII strains. The second round PCR specific for GI strains was carried out with primers G1 and JV13I and for GII strains with primers JV12Y and NoroII-R. For both first and second round PCR, the same reagent and concentration as mentioned for PP7 PCR were used with the exception of $2 \mu$ of template added in the second round PCR. The first round PCR was performed with 40 cycles of $94{ }^{\circ} \mathrm{C}, 30 \mathrm{~s} ; 45^{\circ} \mathrm{C}, 30 \mathrm{~s}$; and $72{ }^{\circ} \mathrm{C}, 45 \mathrm{~s}$ followed by a final extension at $72{ }^{\circ} \mathrm{C}$ for $10 \mathrm{~min}$. The cycling conditions of the second round PCR were the same as the first round PCR with 35 cycles (Boxman et al. 2006)

Detection of HAstV by qualitative RT-PCR was performed with primers Mon269 and Mon270 with the same reagent and concentration as described for PP7 PCR. The cycling conditions were as follows: 40 cycles of $94{ }^{\circ} \mathrm{C}$, $30 \mathrm{~s} ; 50{ }^{\circ} \mathrm{C}, 30 \mathrm{~s}$; and $72{ }^{\circ} \mathrm{C}, 1 \mathrm{~min}$ followed by a final extension at $72{ }^{\circ} \mathrm{C}$ for $10 \mathrm{~min}$ (Noel et al. 1995).
For details of primers used in qualitative PCŔs see Table 1.

Quantitative PCR for Group A Rotaviruses, GII Noroviruses and Human Astroviruses

All quantitative PCRs (qPCR) were carried out with TaqMan ${ }^{\circledR}$ technology. Plasmids containing the insert for each virus analyzed in this study were kindly provided by Dr. T. Fumian from the Laboratory of Comparative and Environmental Virology, Oswaldo Cruz Foundation, Brazil. All qPCR reactions were performed with SensiMix ${ }^{\mathrm{TM}}$ II Probe Kit (Bioline Reagents Ltd.) and Rotor-Gene Q instrument $\left(\right.$ Qiagen $\left.{ }^{\circledR}\right)$ following manufactureŕs recommendations.

Genomic quantification of RVA by qPCR was performed with primers toward the NSP3 gene as described by Zeng et al. (2008) with a standard curve performed with nine points of serial dilutions of plasmid $\left(10^{8}-10^{0}\right.$ genomic 
Table 2 Primers and probes used for viral quantification by quantitative PCR

\begin{tabular}{|c|c|c|c|c|c|}
\hline Virus & Primer/Probe & Sequence $\left(5^{\prime} \rightarrow 3^{\prime}\right)^{\mathrm{a}}$ & Genome region & $\begin{array}{l}\text { Amplicon } \\
\text { size }\end{array}$ & Reference \\
\hline \multirow[t]{3}{*}{ RV } & NSP3f & ACCATCTWCACRTRACCCTCTATGAG & NSP3 & $86 \mathrm{bp}$ & Zeng et al. 2008 \\
\hline & NSP3r & GGTCACATAACGCCCCTATAGC & & & \\
\hline & NSP3 probe & VIC-AGTTAAAAGCTAACACTGTCAAA-MGB & & & \\
\hline \multirow[t]{3}{*}{$\mathrm{NoV}$} & $\mathrm{COG} 2 \mathrm{~F}$ & CARGARBCNATGTTYAGRTGGATGAG & $\begin{array}{l}\text { ORF1-ORF2 } \\
\text { junction }\end{array}$ & $97 \mathrm{bp}$ & Kageyama et al. 2003 \\
\hline & COG2R & TCGACGCCATCTTCATTCACA & & & \\
\hline & RING2-TP probe & FAM-TGGGAGGGCGATCGCAATCT-TAMRA & & & \\
\hline \multirow[t]{3}{*}{ HAstV } & AstVF & CCDGCCAGRCTCACAGAAGAG & ORF1b & $76 \mathrm{bp}$ & Dai et al. 2010 \\
\hline & AstVR & GACTTGCTAGCCATCACACTYC & & & \\
\hline & AstV probe & $\begin{array}{l}\text { FAM-ACTCCATCGCATTTGGAGGGGAG } \\
\text { GACC-TAMRA }\end{array}$ & & & \\
\hline
\end{tabular}

$R V$ rotavirus, $N o V$ norovirus, $H A s t V$ human astrovirus

${ }^{\text {a }}$ Degenerated primers and probes are as follows: Y: C or G; B: not A; N: any. W: A or T; K: G or T; S: G or C

Table 3 Frequency and concentration of group A rotavirus, norovirus, and human astrovirus according to collection sites along Uruguay River

\begin{tabular}{llll}
\hline City & \multicolumn{2}{l}{ Positive $(\%) /$ mean of concentration $($ g.c./l) } & HAstV \\
\cline { 2 - 4 } & RVA & NoV & $10(42) / 4.5 \times 10^{4}$ \\
\hline Bella Unión & $11(46) / 7.5 \times 10^{5}$ & $8(33) / 4.2 \times 10^{5}$ & $15(63) / 7.8 \times 10^{5}$ \\
Salto & $13(54) / 5.4 \times 10^{6}$ & $9(38) / 4.9 \times 10^{5}$ & $7(29) / 6.6 \times 10^{5}$ \\
Paysandú & $14(58) / 2.8 \times 10^{6}$ & $15(63) / 2.0 \times 10^{6}$ & $11(46) / 4.4 \times 10^{6}$ \\
Fray Bentos & $9(38) / 4.6 \times 10^{6}$ & $17(71) / 1.0 \times 1.0^{6}$ & $43(45)$ \\
Total & $47(49)$ & $49(51)$ &
\end{tabular}

g.c./l genomic copies per liter, $R V A$ group A rotavirus, $N o V$ norovirus, HAstV human astrovirus

copies/reaction $(\mathrm{gc} / \mathrm{r}))$ that yield a slope of -3.59 and a reaction efficiency of 0.90 .

Quantification of GII was achieved using the ORF1/ ORF2 junction region with a standard curve performed with the same serial dilutions as the RVA quantification that yields a slope of -3.43 and a PCR efficiency of 0.96 (Kageyama et al. 2003).

qPCR reactions for HAstV were carried out with primers directed to the ORF1b region and a standard curve with the same serial dilutions as RVA quantification (Dai et al. 2010). The slope of this standard curve was -3.31 , and the efficiency of the reaction was 1.01.

For details of primers and probes sequences, genome location and amplicon size see Table 2.

\section{Results}

The high percentage ( $80 \%$ [77/96]) of gastroenteric viruseś detection reveals the spread of those viruses along Uruguay River. NoV was the most frequently detected with $49(51 \%)$ positives samples, GII detected in all 49 samples, and GI detected in only 7 samples. RVA was the second more frequently detected virus with 47 (49\%) positive samples followed by HAstV with 43 (45\%) of the analyzed samples.

All investigated viruses were detected in the four cities studied with detection rates ranging from 29 to $71 \%$ according to the virus and the locality, although nearly the same frequency was observed in Salto $(n=37,51 \%)$, Paysandú $(n=36,50 \%)$, and Fray Bentos $(n=37,51 \%)$ with a slightly low frequency identified in Bella Unión $(n=29,40 \%)$ (Table 3$)$.

The concentration determined by qPCR of each gastroenteric virus ranged between $3.9 \times 10^{3}$ g.c./1 and $4.3 \times 10^{7}$ g.c./1 for RVA, from $3.2 \times 10^{3}$ to $4.3 \times 10^{7}$ g.c. $/$ 1 for HAstV and for NoV, it varied from $2.9 \times 10^{3}$ to $3.8 \times 10^{7}$ g.c./l. A similar pattern of concentration for each virus was observed when analyzing each city with a mean ranging from $10^{4}$ to $10^{6}$ g.c./l; however, a slightly high concentration for RVA over the other viruses was observed in Bella Unión, Salto, Paysandú, and Fray Bentos (Table 3).

By using a multiplex semi-nested RT-PCR for RVA typing, the following genotypes were detected: $\mathrm{P}[8]$ $(n=15), \mathrm{P}[4](n=8), \mathrm{P}[10](n=1), \mathrm{P}[11](n=1), \mathrm{G} 2$ 
Fig. 2 Distribution of group A rotaviruses, noroviruses, and human astroviruses according to the month of collection. The monthly average temperature registered in the area of the study is indicated by a dash line. $R V A$ group A rotavirus, $N o V$ norovirus, HAstV human astrovirus, Avg. Temp. average of the temperature

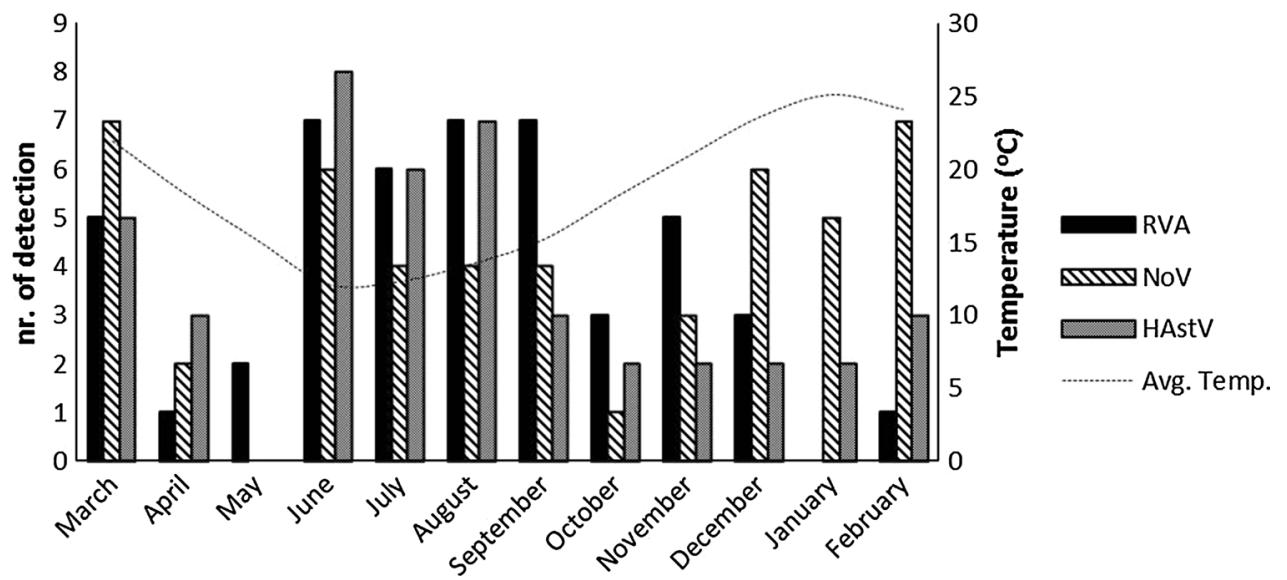

( $n=29)$, and G3 $(n=2)$. PP7 bacteriophage was used as internal control and was detected in all analyzed samples.

A monthly distribution revealed a year round detection of all gastroenteric viruses except for NoV and HAstV that were absent in May and RVA in January. A pattern of seasonality during winter months (June to September) was observed for RVA and HAstV, whereas for NoV, no pattern of seasonality was observed (Fig. 2).

\section{Discussion}

The results of this study reveal the presence of RVA, NoV, and HAstV in sewage directly discharged from four cities (Bella Unión, Salto, Paysandú, and Fray Bentos) into Uruguay River in Uruguay. To our best knowledge, this is the first study in Uruguay describing the presence, frequency, and seasonality of gastroenteric viruses in the environment. Up to this date, several methodologies have been used to concentrate viruses from different kinds of environmental waters, and the choice of the method is based mainly on the matrix to be analyzed (Vilaginès et al. 1993; Pina et al. 1998; Katayama et al. 2002; Calgua et al. 2008). The ultracentrifugation method was used in this study due to its worldwide use for concentrating gastroenteric viruses from sewage samples, since it is robust and simple (Nordgren et al. 2009; Fumian et al. 2010; Prata et al. 2012). Different viruses are used as internal control to evaluate the concentration step and the influence of these inhibitors on viral detection. In this work, we decided to inoculate PP7 bacteriophage in the sewage samples, since it is easy to cultivate and also for offering similar physicochemical properties to gastroenteric viruses (Rajal et al. 2007). Prado et al. (2013) performed the recovery rate of PP7 by ultracentrifugation from sludge samples that was $12 \%$. In all analyzed samples, PP7 was detected after concentration confirming that the ultracentrifugation method is an excellent alternative to study gastroenteric viruses in sewage samples with no interference of different inhibitors on viral detection.

The high percentage of detection and concentration of viruses up to $10^{7}$ g.c./l is consistent with results obtained by direct investigation of sewage highlighting the microbiological contamination of Uruguay River and the impact of human occupation in the quality of water (Fumian et al. 2011; He et al. 2011). This is in agreement with similar results obtained in recent studies carried out in developed as well in developing countries, which determined a significant range of NoV positivity in sewage samples ( $\mathrm{La}$ Rosa et al. 2010; Bucardo et al. 2011; Kitajima et al. 2012). The frequency of NoV detected in this study is higher than the frequency detected by He et al. (2011) in sewage from three sewage treatment plants in China. However, it was similar to the frequency detected in studies performed in Argentina and Brazil (Victoria et al. 2010; Blanco Fernández et al. 2011). On the other hand, La Rosa et al. (2010) identified nearly $100 \%$ of positivity for NoV in the influent in five wastewater treatment plants in Italy. However, it is important to take in account that PCR methods performed for $\mathrm{NoV}$ detection in the previously mentioned studies were different, and the comparison between the percentages of positives is not linear, because some of these results can be augmented by the combination of more than one PCR methodology.

The frequency of RVA was surprising mainly due to several studies carried out in Latin America where RVA is generally the predominant virus in the environment reflecting the large number of cases that is still reported in those countries, even after the introduction of the rotavirus vaccine as occurred in Brazil (Miagostovich et al. 2008; Barril et al. 2010; Vieira et al. 2012; da Silva Soares et al. 2013; Degiuseppe et al. 2013; Fumian et al. 2013; Keller et al. 2013).

The multiplex semi-nested RT-PCR for detection and genotyping RVA present in sewage samples was performed, since it is important to determine the genotypes 
present in the environment and to get an insight of the viruseś epidemiology as well as surveillance of the dynamic of these genotypes in a country where a RVA vaccine has not yet been included in the national vaccination schedule. Although it is not possible to make an association between genotypes in environmental samples, it was interesting to note the predominance of genotypes $\mathrm{P} 8$ and $\mathrm{G} 2$ in the environment, which usually are not associated. In general, it has been observed that there is a global presence of human G1, G3, G4, G9 (commonly associated with $\mathrm{P}[8]), \mathrm{G} 2$ that is generally associated with $\mathrm{P}[4]$ and G12 predominantly associated with either $\mathrm{P}[8]$ or $\mathrm{P}[6]$; while $\mathrm{P}[10]$ and $\mathrm{P}[11]$ are considered as suspected human/ animal reassortant strains mainly isolated from humans (Matthijnssens et al. 2009). The predominance of G2 has also been observed in neighboring countries, and discussion on the influence of the vaccine on the dynamics of fluctuating RVA genotypes has been raised, mainly in Brazil (Leite et al. 2008; Degiuseppe et al. 2013). G2 genotype has been prevalent in clinical surveillance studies performed in Rio de Janeiro, Brazil and was widely detected in sewage samples collected in a sewage treatment plant located in the same city (Fumian et al. 2010; Carvalho-Costa et al. 2011). Unfortunately, only one report describing $G$ genotypes in clinical samples collected between 1996 and 1999 was carried out in Uruguay highlighting the need of conducting further studies concerning the circulating RVA genotypes in order to determine the epidemiology of this virus in the pediatric population in this country (Berois et al. 2003).

HAstV presented the lowest frequency of the gastroenteric viruses analyzed in this study with $45 \%$ of positivity. A higher frequency was observed in a study performed in Singapore where all sewage samples were positives; however, it was higher when compared with the detection rates observed in sewage treatment plants in Brazil and China. Similar results were observed concerning the quantification of positive samples (Aw and Gin, 2010; He et al. 2011; Fumian et al. 2013). This fluctuation of the frequency as well as the concentration of $\mathrm{HAstV}$ in sewage samples can be explained by the different methodology and genome targets used in these studies as well as by the different patterns of HAstV epidemiology in each analyzed country

Although this is only a 1-year monitoring of these viruses in order to investigate its seasonality pattern, the detection peak for RVA and HAstV is frequently observed both in clinical and environmental surveillance, which leads us to think that it is likely that in colder months, both RVA and $\mathrm{HAstV}$ are frequently present in the pediatric population in those cities (Medici et al. 2012). On the other hand, no seasonality pattern was observed for NoV. This is in agreement with a recent study performed by Bucardo et al. (2011) which detected NoV in Nicaragua throughout the year. Nevertheless, gastroenteritis cases due to NoV infections are generally associated with peaks of infections during the winter months in temperate countries like Uruguay (Karst 2010; Mounts et al. 2000). It must be taken into account that during environmental monitoring both symptomatic and asymptomatic cases of gastroenteritis caused by NoV infections are detected, and it is well known that a high prevalence of asymptomatic infections of NoV is frequently present in the population (Zhang et al. 2011).

This study demonstrated an elevated frequency of RVA, $\mathrm{NoV}$, and HAstV in sewage samples collected in Uruguay (Bella Unión, Salto, Paysandú, and Fray Bentos), highlighting the need of investing in sewage treatment plants to reduce the impact of movement of virus in the population and the risk of acute gastroenteritis for the local population, since sewage is directly discharged in the waters of Uruguay River; widely used for recreation activities and also for drinking.

Acknowledgments We want to thank the financial support by the program "Polo de Desarrollo Universitario" (PDU), Universidad de la República (UdelaR), Uruguay; Project PCPP 023/2011 of "Coordenação de Aperfeiçoamento de Pessoal de Nível Superior" (CAPES, Brazil), "Agencia Nacional de Investigación e Innovación" through project ANII-ALI-2009-1-1603 and project CSIC I + D 2010, Universidad de la República (UdelaR). We thank Sección Bioquímica, Instituto de Biología, Facultad de Ciencias and Instituto Pasteur, Montevideo, Uruguay, for technical assistance.

\section{References}

Aw, T. G., \& Gin, K. Y. (2010). Environmental surveillance and molecular characterization of human enteric viruses in tropical urban wastewaters. Journal of Applied Microbiology, 109(2), 716-730.

Barreira, D. M., Ferreira, M. S., Fumian, T. M., Checon, R., de Sadovsky, A. D., Leite, J. P., et al. (2010). Viral load and genotypes of noroviruses in symptomatic and asymptomatic children in Southeastern Brazil. Journal of Clinical Virology, 47(1), 60-64.

Barril, P. A., Giordano, M. O., Isa, M. B., Masachessi, G., Ferreyra, L. J., Castello, A. A., et al. (2010). Correlation between rotavirus A genotypes detected in hospitalized children and sewage samples in 2006, Córdoba Argentina. Journal of Medical Virology, 82(7), $1277-1281$.

Berois, M., Libersou, S., Russi, J., Arbiza, J., \& Cohen, J. (2003). Genetic variation in the VP7 gene of human rotavirus isolated in Montevideo-Uruguay from 1996-1999. Journal of Medical Virology, 71(3), 456-462.

Black, R. E., Morris, S. S., \& Bryce, J. (2003). Where and why are 10 million children dying every year? Lancet, 361(9376), 2226-2234.

Blanco Fernández, M. D., Torres, C., Martínez, L. C., Giordano, M. O., Masachessi, G., Barril, P. A., et al. (2011). Genetic and evolutionary characterization of norovirus from sewage and surface waters in Córdoba City Argentina. Infection, Genetics and Evolution, 11(7), 1631-1637.

Boom, R., Sol, C. J., Salimans, M. M., Jansen, C. L., Wertheim-van Dillen, P. M., \& van der Noordaa, J. (1990). Rapid and simple 
method for purification of nucleic acids. Journal of Clinical Microbiology, 28(3), 495-503.

Boxman, I. L., Tilburg, J. J., Te Loeke, N. A., Vennema, H., Jonker, K., de Boer, E., et al. (2006). Detection of noroviruses in shellfish in The Netherlands. International Journal of Food Microbiology, 108(3), 391-396.

Bucardo, F., Lindgren, P. E., Svensson, L., \& Nordgren, J. (2011). Low prevalence of rotavirus and high prevalence of norovirus in hospital and community wastewater after introduction of rotavirus vaccine in Nicaragua. PLoS ONE, 6(10), e25962.

Calgua, B., Mengewein, A., Grunert, A., Bofill-Mas, S., ClementeCasares, P., Hundesa, A., et al. (2008). Development and application of a one-step low cost procedure to concentrate viruses from seawater samples. Journal of Virological Methods, 153(2), 79-83.

C.A.R.U. Comisión Administradora del Río Uruguay. (2013). El Río Uruguay en cifras. http://www.caru.org.uy/web/acerca-de/ prueba-pagina. Accessed 15 October 2013.

Carvalho-Costa, F. A., Volotão Ede, M., de Assis, R. M., Fialho, A. M., de Andrade Jda, S., Rocha, L. N., et al. (2011). Laboratorybased rotavirus surveillance during the introduction of a vaccination program, Brazil, 2005-2009. The Pediatric Infectious Disease Journal, 30(1 Suppl), S35-S41.

Chan, M. C., Sung, J. J., Lam, R. K., Chan, P. K., Lee, N. L., Lai, R. W., et al. (2006). Fecal viral loadand norovirus-associated gastroenteritis. Emerging Infectious Diseases, 12(8), 1278-1280.

Churgay, C. A., \& Aftab, Z. (2012). Gastroenteritis in children: Part 1 Diagnosis. American Family Physician, 85(11), 1059-1062.

da Silva Soares L, de Fátima Dos Santos Guerra S, do Socorro Lima de Oliveira A, da Silva Dos Santos F, de Fátima Costa de Menezes EM, Mascarenhas JD, Linhares AC. (2013). Diversity of rotavirus strains circulating in Northern Brazil after introduction of a rotavirus vaccine: High prevalence of G3P[6] genotype. Journal of Medical Virology, doi: 10.1002/jmv. 23797.

Dai, Y. C., Xu, Q. H., Wu, X. B., Hu, G. F., Tang, Y. L., Li, J. D., et al. (2010). Development of real-time and nested RT-PCR to detect astrovirus and one-year survey of astrovirus in Jiangmen City China. Archives of Virology, 155(6), 977-982.

Degiuseppe, J. I., Giovacchini, C., \& Stupka, J. A. (2013). Red Nacional de Vigilancia de Gastroenteritis Virales. [Rotavirus epidemiology and surveillance in Argentina: 2009-2011]. Archivos Argentinos de Pediatría, 111(2), 148-154.

Desselberger, U. (1999). Rotavirus infections: Guidelines for treatment and prevention. Drugs, 58(3), 447-452.

Ehlers, M. M., Grabow, W. O., \& Pavlov, D. N. (2005). Detection of enteroviruses in untreated and treated drinking water supplies in South Africa. Water Research, 39(11), 2253-2258.

Espinosa, A. C., Mazari-Hiriart, M., Espinosa, R., Maruri-Avidal, L., Méndez, E., \& Arias, C. F. (2008). Infectivity and genome persistence of rotavirus and astrovirus in groundwater and surface water. Water Research, 42(10-11), 2618-2628.

Fumian, T. M., Leite, J. P., Castello, A. A., Gaggero, A., Caillou, M. S., \& Miagostovich, M. P. (2010). Detection of rotavirus A in sewage samples using multiplex qPCR and an evaluation of the ultracentrifugation and adsorption-elution methods for vírus concentration. Journal of Virological Methods, 170(1-2), 42-46.

Fumian, T. M., Leite, J. P., Rose, T. L., Prado, T., \& Miagostovich, M. P. (2011). One year environmental surveillance of rotavirus specie A (RVA) genotypes in circulation after the introduction of the Rotarix ${ }^{\circledR}$ vaccine in Rio de Janeiro Brazil. Water Research, 45(17), 5755-5763.

Fumian, T. M., Vieira, C. B., Leite, J. P., \& Miagostovich, M. P. (2013). Assessment of burden of virus agents in an urban sewage treatment plant in Rio de Janeiro Brazil. Journal OF Water and Health, 11(1), 110-119.
Gallimore, C. I., Cubitt, D., du Plessis, N., \& Gray, J. J. (2004). Asymptomatic and symptomatic excretion of noroviruses during a hospital outbreak of gastroenteritis. Journal of Clinical Microbiology, 42(5), 2271-2274.

Gerba, C. P., Gramos, D. M., \& Nwachuku, N. (2002). Comparative inactivation of enteroviruses and adenovirus 2 by UV light. Applied and Environment Microbiology, 68(10), 5167-5169.

He, X. Q., Cheng, L., Zhang, D. Y., Xie, X. M., Wang, D. H., \& Wang, Z. (2011). One-year monthly survey of rotavirus, astrovirus and norovirus in three sewage treatment plants (STPs) in Beijing, China and associated health risk assessment. Water Science and Technology, 64(6), 1202-1210.

I.B.G.E. Instituto Brasileiro de Geografia e Estatística. (2013). http:// www.ibge.gov.br/home/. Accessed 15 October 2013.

I.N.D.E.C. Instituto Nacional de Estadística y Censos. (2013). http:// www.indec.mecon.ar/. Accessed 15 October 2013.

I.N.E. Instituto Nacional de Estadística. (2013). http://www.ine.gub. uy/. Accessed 15 October 2013.

Kageyama, T., Kojima, S., Shinohara, M., Uchida, K., Fukushi, S., Hoshino, F. B., et al. (2003). Broadly reactive and highly sensitive assay for Norwalk-like viruses based on real-time quantitative reverse transcription-PCR. Journal of Clinical Microbiology, 41(4), 1548-1557.

Karst, S. M. (2010). Pathogenesis of noroviruses, emerging RNA viruses. Viruses, 2(3), 748-781.

Katayama, H., Shimasaki, A., \& Ohgaki, S. (2002). Development of a virus concentration method and its application to detection of enterovirus and norwalk virus from coastal seawater. Applied and Environment Microbiology, 68(3), 1033-1039.

Keller, R., Justino, J. F., \& Cassini, S. T. (2013). Assessment of water and seafood microbiology quality in a mangrove region in Vitória Brazil. Journal of Water and Health, 11(3), 573-580.

Kitajima, M., Haramoto, E., Phanuwan, C., Katayama, H., \& Furumai, H. (2012). Molecular detection and genotyping of human noroviruses in influent and effluent water at a wastewater treatment plant in Japan. Journal of Applied Microbiology, 112(3), 605-613.

La Rosa, G., Iaconelli, M., Pourshaban, M., \& Muscillo, M. (2010). Detection and molecular characterization of noroviruses from five sewage treatment plants in central Italy. Water Research, 44(6), 1777-1784.

Leite, J. P., Carvalho-Costa, F. A., \& Linhares, A. C. (2008). Group A rotavirus genotypes and the ongoing Brazilian experience: a review. Memorias do Instituto Oswaldo Cruz, 103(8), 745-753.

Li, D., Gu, A. Z., He, M., Shi, H. C., \& Yang, W. (2009). UV inactivation and resistance of rotavirus evaluated by integrated cell culture and real-time RT-PCR assay. Water Research, 43(13), 3261-3269.

Matthijnssens, J., Bilcke, J., Ciarlet, M., Martella, V., Bányai, K., Rahman, M., et al. (2009). Rotavirus disease and vaccination: impact on genotype diversity. Future Microbiology, 4(10), $1303-1316$.

Medici, M. C., Tummolo, F., Albonetti, V., Abelli, L. A., Chezzi, C., \& Calderaro, A. (2012). Molecular detection and epidemiology of astrovirus, bocavirus, and sapovirus in Italian children admitted to hospital with acute gastroenteritis, 2008-2009. Journal of Medical Virology, 84(4), 643-650.

Miagostovich, M. P., Ferreira, F. F., Guimarães, F. R., Fumian, T. M., Diniz-Mendes, L., Luz, S. L., et al. (2008). Molecular detection and characterization of gastroenteritis viruses occurring naturally in the stream waters of Manaus, central Amazonia Brazil. Applied and Environmental Microbiology, 74(2), 375-382.

Mounts, A. W., Ando, T., Koopmans, M., Bresee, J. S., Noel, J., \& Glass, R. I. (2000). Cold weather seasonality of gastroenteritis associated with Norwalk-like viruses. Journal of Infectious Diseases, 181(Suppl 2), S284-S287. 
Noel, J. S., Lee, T. W., Kurtz, J. B., Glass, R. I., \& Monroe, S. S. (1995). Typing of human astroviruses from clinical isolates by enzyme immunoassay and nucleotide sequencing. Journal of Clinical Microbiology, 33(4), 797-801.

Nordgren, J., Matussek, A., Mattsson, A., Svensson, L., \& Lindgren, P. E. (2009). Prevalence of norovirus and factors influencing virus concentrations during one year in a full-scale wastewater treatment plant. Water Research, 43(4), 1117-1125.

O'Ryan, M. L., Lucero, Y., Prado, V., Santolaya, M. E., Rabello, M., Solis, Y., et al. (2009). Symptomatic and asymptomatic rotavirus and norovirus infections during infancy in a Chilean birth cohort. The Pediatric Infectious Disease Journal, 28(10), 879-884.

Payne, D. C., Vinjé, J., Szilagyi, P. G., Edwards, K. M., Staat, M. A., Weinberg, G. A., et al. (2013). Norovirus and medically attended gastroenteritis in US children. New England Journal of Medicine, 368(12), 1121-1130.

Pina, S., Jofre, J., Emerson, S. U., Purcell, R. H., \& Girones, R. (1998). Characterization of a strain of infectious hepatitis $E$ virus isolated from sewage in an area where hepatitis $E$ is not endemic. Applied and Environment Microbiology, 64(11), 4485-4488.

Prado, T., Guilayn Wde, C., Gaspar, A. M., \& Miagostovich, M. P. (2013). The efficiency of concentration methods used to detect enteric viruses in anaerobically digested sludge. Memorias do Instituto Oswaldo Cruz, 108(1), 77-83.

Prata, C., Ribeiro, A., Cunha, Â., Gomes, N. C., \& Almeida, A. (2012). Ultracentrifugation as a direct method to concentrate viruses in environmental waters: virus-like particle enumeration as a new approach to determine the efficiency of recovery. Journal of Environmental Monitoring, 14(1), 64-70.

Rajal, V. B., McSwain, B. S., Thompson, D. E., Leutenegger, C. M., Kildare, B. J., \& Wuertz, S. (2007). Validation of hollow fiber ultrafiltration and real-time PCR using bacteriophage PP7 as surrogate for the quantification of viruses from water samples. Water Research, 41(7), 1411-1422.

Seitz, S. R., Leon, J. S., Schwab, K. J., Lyon, G. M., Dowd, M., McDaniels, M., et al. (2011). Norovirus infectivity in humans and persistence in water. Applied and Environment Microbiology, 77(19), 6884-6888.

Teunis, P. F., Moe, C. L., Liu, P., Miller, S. E., Lindesmith, L., Baric, R. S., et al. (2008). Norwalk virus: how infectious is it? Journal of Medical Virology, 80(8), 1468-1476.

Victoria, M., Guimarães, F. R., Fumian, T. M., Ferreira, F. F., Vieira, C. B., Shubo, T., et al. (2010). One year monitoring of norovirus in a sewage treatment plant in Rio de Janeiro Brazil. Journal of Water and Health, 8(1), 158-165.

Vieira, C. B., Mendes, A. C., Guimarães, F. R., Fumian, T. M., Leite, J. P., Gaspar, A. M., et al. (2012). Detection of enteric viruses in recreational waters of an urban lagoon in the city of Rio de Janeiro Brazil. Memórias do Instituto Oswaldo Cruz, 107(6), $778-784$.

Vilaginès, P., Sarrette, B., Husson, G., \& Vilaginès, R. (1993). Glass wool for virus concentration at ambient water $\mathrm{pH}$ level. Water Science and Technology, 27(3-4), 299-306.

Wazny, K., Zipursky, A., Black, R., Curtis, V., Duggan, C., Guerrant, R., et al. (2013). Setting research priorities to reduce mortality and morbidity of childhood diarrhoeal disease in the next 15 years. PLoS Medicine, 10(5), e1001446.

World Health Organization (2009a). Diarrhoea: Why children are still dying and what can be done.

World Health Organization (2009b). Manual of rotavirus detection and characterization methods.

Wyn-Jones, A. P., Carducci, A., Cook, N., D’Agostino, M., Divizia, M., Fleischer, J., et al. (2011). Surveillance of adenoviruses and noroviruses in European recreational waters. Water Research, 45(3), 1025-1038.

Zeng, S. Q., Halkosalo, A., Salminen, M., Szakal, E. D., Puustinen, L., \& Vesikari, T. (2008). One-step quantitative RT-PCR for the detection of rotavirus in acute gastroenteritis. Journal of Virological Methods, 153(2), 238-240.

Zhang, S., Chen, T. H., Wang, J., Dong, C., Pan, J., Moe, C., et al. (2011). Symptomatic and asymptomatic infections of rotavirus, norovirus, and adenovirus among hospitalized children in Xi' an China. Journal of Medical Virology, 83(8), 1476-1484. 